DOI 10.18551/rjoas.2021-09.19

\title{
THE ANTIFUNGAL ACTIVITY OF ENDOPHYTE FUNGUS FROM RUBBER LEAVES IN VITRO AND ITS ANTAGONIST MECHANISM OF COLLETOTRICHUM GLOEOSPORIOIDES
}

\author{
Syamsafitri* \\ Doctoral Program of Agricultural Sciences, Faculty of Agriculture, \\ Universitas Sumatera Utara, JI. Prof. A. Sofyan No. 3, Padang Bulan 20155, Indonesia
}

\section{Bakti Darma, Lisnawita}

Department of Agrotecnology, Faculty of Agriculture, Universitas Sumatera Utara, Jl. Prof. A. Sofyan No. 3, Padang Bulan 20155, Indonesia

\author{
Tistama Radite \\ Sungai Putih Rubber Research Center-Galang, Sumatera Utara, P.O Box 1415 Medan 2000, \\ Indonesia \\ *E-mail: syamsafitri@yahoo.co.id
}

\begin{abstract}
Rubber tree disease is the most important disturbing factor compared to other disorders. There have been found 25 types of diseases in rubber estate, and the most important one is Colletotrichum leaf spot caused by Colletotrichum gloesporioides. Recently, biological control for plant disease using various antagonistic fungi has begun to develop. This study aims to analyze in vitro anti-fungal activity of endophytic fungi from rubber leaves and their antagonistic mechanisms against $\mathrm{C}$. gloesporioides. This research was conducted with dual culture experiments of endophytic fungi isolates against $\mathrm{C}$. gloesporioides fungi to find out the inhibitory power by analyze of growth rate Endophytic colony and Inhibition of Endophytes by invitro. The results showed that Endophytic fungal isolates were able to suppress the growth of $\mathrm{C}$. gloesporioides. From the 14 treatments of endophytic fungal isolates, the most effective consistency of inhibition with the highest inhibition percentage, namely $92.58 \%$, was found in isolates from Bandar Betsy 1 (BB1).
\end{abstract}

\section{KEY WORDS}

Rubber, disease, Colletotrichum gloesporioides, endophytic fungi, antagonist, in vitro.

Indonesia is the second largest producer of natural rubber in the world after Thailand, with a growth in planted area of $1.14 \%$ per year from 1980-2019, that is from 2.38 million ha in 1980 to 3.68 million ha in 2019. Accordingly, rubber production growth in Indonesia has also increased from 2010 to 2017 with an average growth of 3.94\% per year, even production reaching 3.6 million tonnes in 2017 (Ministry of Agriculture, 2019). This data shows that rubber plantations area is the second largest after oil palm and the most important plantation commodity in Indonesia.

Rubber trees disease is the most important disruptive factor compared to other disturbances, and often thwart farming effort. It was found 25 types of diseases that can cause damage in rubber estate (Hunupolagama et al., 2017). Today, one of the threat to rubber cultivation is a number of diseases in various stages of growth, such as abnormal leaf fall, one of which is Colletotrichum leaf spot caused by Colletotrichum gloesporioides (Edathil et al. , 2000). In addition to causing a decrease in production, disease often results in the failure of a rubber development program.

Anthracnose disease caused by $C$. gloesporioides from Glomerella group is very common and devastating for many plants worldwide (Münch et al., 2008; Kim et al., 2002; Lubbe et al., (2004). C. gloesporioides Leaf Disease (CLD) of rubber trees is considered to be one of the main causes of decline in rubber yields in the Asian continent (Liu et al., 1987). 
The direct effect of this disease is necrosis and leaf deformation, namely fall of the youngest infected leaves at an early stage of development. As a result, new leaves produced throughout the rainy season will be systematically damaged or fallen by this disease. This disease epidemic causes a substantial reduction in foliage density and the death of the main branches, known as die-back (Jean et al., 2001).

So far, the control of $C$. gloesporioides leaf disease is using chemicals. Excessive use of chemicals to control $C$. gloesporioides has a negative impact, namely environmental pollution and the death of non-targeted organisms around rubber estate (Purnomo, 2011). Recently, biological plant disease control using various antagonistic fungi has begun to develop. Previous researchers have been reported that antagonistic microorganisms can suppress the growth and development of pathogens through the mechanism of antibiosis (formation of antibiotics, bacteriocins, toxins and hydrolysis enzymes), parasitism, and competition. There are many species of biological agents that believed able to suppress the development of pathogens (Bulan et al., 2012). Recent research states that endophytic fungi are important components of plant microbiota, and have an excellent capacity to produce various kinds of bioactive metabolites (Ding et al, 2019). This bioactive metabolite was effective in reducing the incidence of leaf fall disease by $53.15 \%$ (Firdaus et al, 2020).

Research purpose: to analyze the anti-fungal activity of endophytic fungi from rubber leaves in vitro and their antagonistic mechanisms against $C$. gloesporioides.

\section{MATERIALS AND METHODS OF RESEARCH}

The materials used in this study were PDA (Potato Dextrose Agar) media, endophytic fungal isolates with codes HPS1, HPS2, HPS3, KI1, KI2, KI3, BB1, BB2, BB3, BB4, SP1, SP2, SP3 SP4, BT1, BT2, sterile distilled water, methylated spirits, cotton, C. gloesporioides fungi culture, $70 \%$ alcohol, disc paper, tissue and cotton. The tools used in this research are laminar flow cabinet, autoclave, oven, petri dish, ose needle, bunsen, gas stove, glass stirrer, flask, tweezers, incubator, aluminum voil, microscope, cover glass, object glass, measuring cup, test tubes, volume pipettes, Erlenmeyer, rulers, media bottles, incubators, analytical scales, scissors, and micro pipettes. vacuum discs. Watman filter paper No.1. etc

The experimental method is dual culture of endophytic fungi isolates against $C$. gloesporioides. The experimental method is non-factorial completely randomized design (CRD) with 5 replications to determine the inhibitory power

Dual culture antagonism test is by preparing PDA media in a petri dish $(9 \mathrm{~cm}$ in diameter), then put a mark on the bottom of the petri dish. Pure endophytic fungi isolates were taken with a $0.5 \mathrm{~cm}$ diameter cork drill at the edge of the colony. Then the fungus pieces were placed on PDA media with a distance of $2 \mathrm{~cm}$ from the edge of the petri dish (mark A). Pathogenic isolates that had been prepared were taken using a cork drill with a diameter of $0.5 \mathrm{~cm}$ from the edge of the colony, then the pieces of pathogenic fungi were placed on PDA media with a distance of $2 \mathrm{~cm}$ from the edge of the petri dish (mark P). As a control, the same thing was done on different petri.

Interaction of endophytic fungi and $C$. gloesporioides can be done by placing in a petri dish with a diameter of $9 \mathrm{~cm}$. C. gloesporioides and endophytic fungi facing each other, then placing a glass object that has been given a thin PDA layer in the middle. Observation of this interaction form is carried out after the meeting of the two ends of the fungus occurs by lifting the glass object. Furthermore, it is dripped with methyl blue and the form of interactions between pathogens and endophytic fungi observed under a microscope. Isolates were inoculated into a flask containing $250 \mathrm{~mL}$ of complete medium, and shaken at $120 \mathrm{rpm}$ for 3 weeks at $27^{\circ} \mathrm{C}$. Fungal mycelium was removed by simple filtration and $100 \mathrm{~mL}$ of the filtrate was extracted with $2 x$ the amount of ethyl acetate and concentrated to a volume of $5 \mathrm{~mL}$ using a rotary evaporator (NPC, Trenton, New Jersey). Five-millimeter paper filter paper immersed in extract or in pure ethyl acetate as a control.

Ethyl acetate was allowed to evaporate from the filter paper under a clean bench, and one extract-soaked filter paper was placed next to a $25 \%$ PDA Petri dish, with the control filter paper on the opposite side allowing $6 \mathrm{~cm}$ of between. The five-millimeter plug from each 
pathogen was transferred to the center of the plate so that it was $3 \mathrm{~cm}$ away from each filter paper. The colonies were allowed to grow for 2, 4, 6 and 8 days. The growth of fungal colonies to the extract-soaked filter disk was measured and compared with the growth to the control. The test was carried out in three replications.

Observed Variables: growth rate Endophytic colony; Inhibition of Endophytes by invitro.

The inhibition power is calculated by the percentage of inhibition using the formula by Asrul (2009).

Data were analyzed using analysis of variance $(P<0.05)$ and Duncan's multiple range test with SPSS software version 10.0 (SPSS Inc., Chicago, USA).

\section{RESULTS AND DISCUSSION}

According to the test results of endophytic fungal isolates against $C$. gloesporioides on 4 observations (2, 4, 6 and 8 days after incubation (DAI)), from 14 isolates of antagonistic endophytic fungi originating from 4 locations, isolates from Bandar Betsy 1 (BB1) shows the consistency of the most effective inhibition value with the highest percentage of inhibitory power, namely $65.25 \%, 84.82 \%, 92.52 \%$ and $92.58 \%$, respectively. Isolates from Kebun Inong 3 also show quite effective inhibition, especially in the 3 initial observation periods $(63.26 \%, 84.57 \%$ and $91.10 \%)$, but in the last observation (8 DAI) the inhibition power slightly decreased (76.07\%). On the other hand, isolates from Bandar Betsy 2 had the opposite character than Kebun Inong 3 isolates, that is in the first 3 observations their inhibition was quite low $(46.03 \%, 52.19 \%$ and $54.16 \%)$, and the inhibition power on the 8 DAI increased sharply to $92.55 \%$. The weakest inhibition of endophytic fungal isolates is found at SP 1, 2, 3, 4 with a percentage of inhibition $<50 \%$, even on observations 2 and 4 DAI showed a negative value (-) as shown in Figure 1. The inhibition of endophytic fungi isolates from Kebun Hapesong, kebun Inong, Bandar Betsy, and Sungai Putih against $C$. gloesporioides showed that the fourteen tested isolates had different inhibitory capacities (Table 1).

Table 1 - Percentage of inhibitory power test on endophytic fungi (\%)

\begin{tabular}{lllll}
\hline \multirow{2}{*}{ Treatment } & \multicolumn{3}{c}{ Inhibitory power (\%) } \\
\cline { 2 - 5 } & $2 \mathrm{HSI}$ & $4 \mathrm{HSI}$ & $6 \mathrm{HSI}$ & $8 \mathrm{HSI}$ \\
\hline Kontrol & $0.00^{\mathrm{d}}$ & $0.00^{\mathrm{b}}$ & $0.00^{\mathrm{a}}$ & $0.00^{\mathrm{a}}$ \\
HPS1 & $4.23^{\mathrm{e}}$ & $-24.61^{\mathrm{b}}$ & $24.87^{\mathrm{b}}$ & $42.75^{\mathrm{c}}$ \\
HPS2 & $21.25^{\dagger}$ & $66.67^{\mathrm{c}}$ & $76.18^{\dagger}$ & $39.30^{\mathrm{c}}$ \\
HPS3 & $-12.30^{\mathrm{c}}$ & $43.90^{\mathrm{c}}$ & $55.06^{\mathrm{d}}$ & $78.84^{\mathrm{d}}$ \\
KI1 & $4.76^{\mathrm{e}}$ & $-7.73^{\mathrm{b}}$ & $26.59^{\mathrm{b}}$ & $53.81^{\mathrm{c}}$ \\
KI2 & $20.87^{\dagger}$ & $65.32^{\mathrm{c}}$ & $72.47^{\dagger}$ & $10.38^{\mathrm{a}}$ \\
KI3 & $63.26^{\mathrm{g}}$ & $84.57^{\mathrm{d}}$ & $91.10^{\dagger}$ & $76.07^{\mathrm{d}}$ \\
BB1 & $65.25^{\mathrm{g}}$ & $84.82^{\mathrm{d}}$ & $92.52^{\dagger}$ & $92.58^{\mathrm{d}}$ \\
BB2 & $46.03^{\mathrm{g}}$ & $52.19^{\mathrm{c}}$ & $54.16^{\mathrm{d}}$ & $92.55^{\mathrm{d}}$ \\
BB3 & $39.82^{\mathrm{g}}$ & $54.85^{\mathrm{c}}$ & $70.53^{\mathrm{e}}$ & $49.45^{\mathrm{c}}$ \\
BB4 & $-7.65^{\mathrm{c}}$ & $7.16^{\mathrm{b}}$ & $40.29^{\mathrm{c}}$ & $77.66^{\mathrm{d}}$ \\
SP1 & $-36.07^{\mathrm{b}}$ & $-1.72^{\mathrm{b}}$ & $34.16^{\mathrm{c}}$ & $46.41^{\mathrm{c}}$ \\
SP2 & $-11.69^{\mathrm{c}}$ & $1.59^{\mathrm{b}}$ & $35.89^{\mathrm{c}}$ & $39.39^{\mathrm{c}}$ \\
SP3 & $-9.85^{\mathrm{c}}$ & $5.95^{\mathrm{b}}$ & $41.67^{\mathrm{c}}$ & $32.06^{\mathrm{b}}$ \\
SP4 & $-49.10^{\mathrm{a}}$ & $-32.26^{\mathrm{a}}$ & $5.31^{\mathrm{a}}$ & $48.80^{\mathrm{c}}$ \\
\hline
\end{tabular}

Note: The numbers followed by different letter in the same column are significantly different in the $1 \%$ Duncan test.

The presence of negative (-) values for the inhibition in 2 and 4 DAl indicates that the antagonistic mechanism occurs for HPS3, BB4, SP.1.2.3.4 isolates and presumed due to inhibition mechanism of antibiosis. This is supported by metabolites compound analysis produced by these endophytic fungi (see table 11) which included in the class of antimicrobial, antioxidant and enzyme. Thus it can be said that antagonistic ability of SP, 1.2.3.4 to inhibit the development and growth of pathogenic fungi $C$. gloesporioides is an antibiotic mechanism. The low inhibition value of the endophytic isolates from Sungai Putih code SP.1.2.3.4 was thought due to both of $\mathrm{C}$. gloesporioides isolates came from clone PB 
260 originated from Kebun Sungai Putih so that adaptation had occurred among the isolates and $C$. gloesporioides which reduce the virulence of these endophytic fungi. According to Wang and Dai (2011), endophytes coexist with host plants and also synthesize biologically active substances similar to secondary metabolites produced by their host plants, thus the metabolite compounds produced by endophytic fungi SP1, SP2, SP3 and SP4 have lower ability to inhibit growth the fungus $C$. gloesporioides.

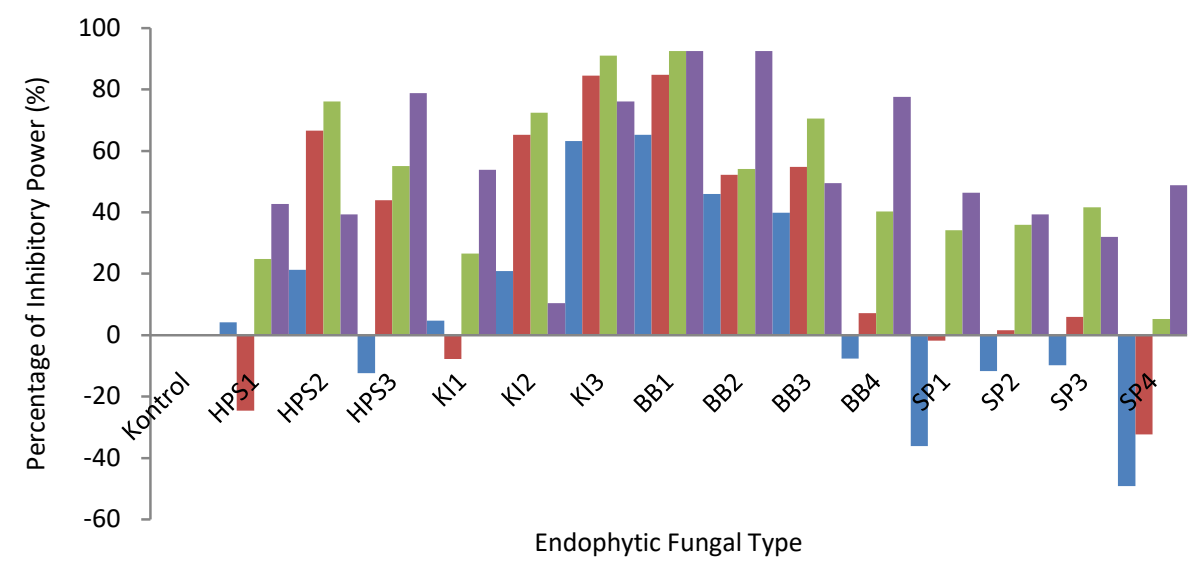

Figure 1 - Relationship between Endophytic Fungal Isolates and Percentage pf Endophyte Inhibition $(\mathrm{cm})$
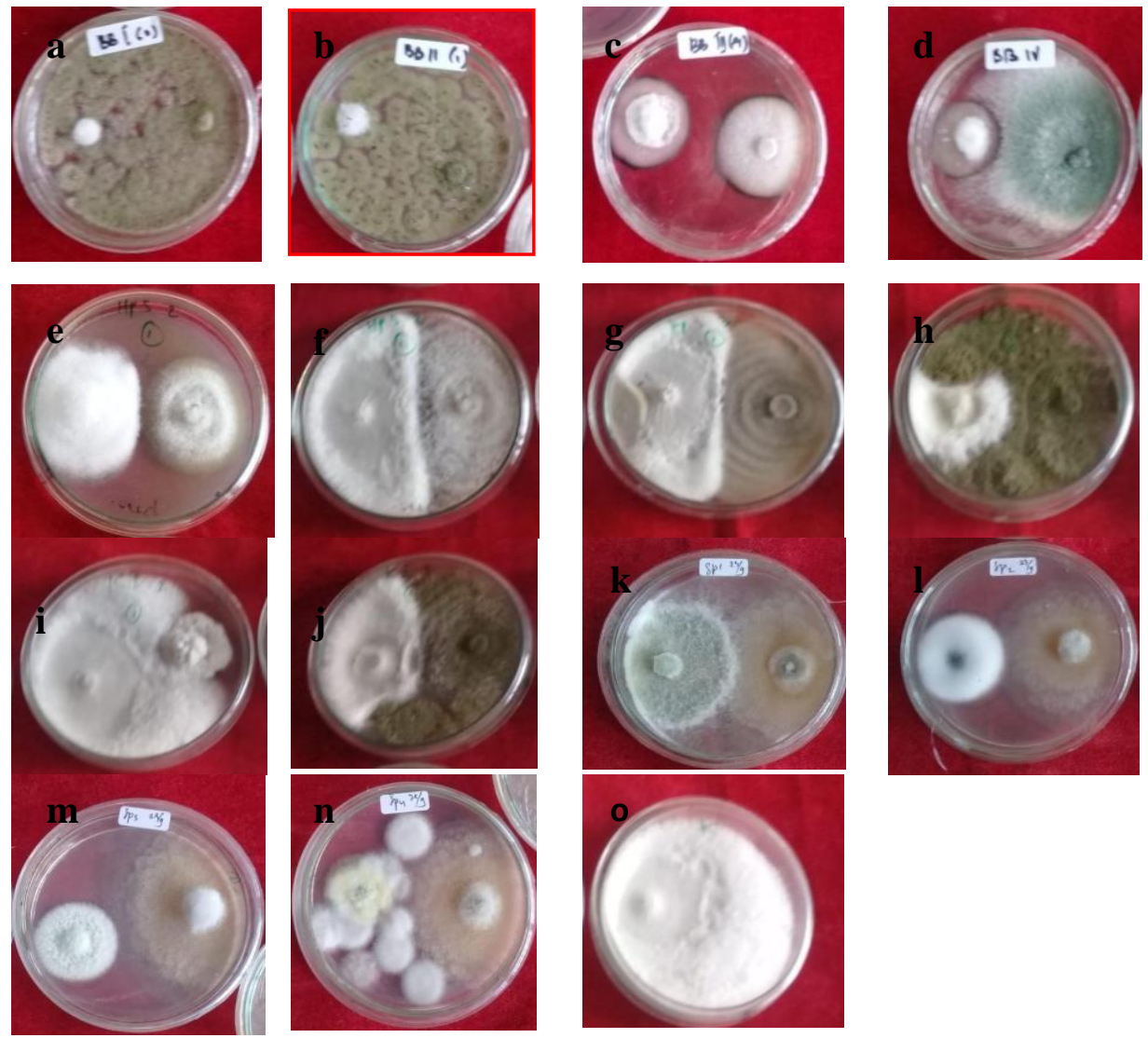

Figure 2 - Dual culture isolate (a) BB1 vs $\mathrm{Cg}$,(b) BB2 vs $\mathrm{Cg}$, (c) BB3 vs $\mathrm{Cg}$, (d) BB4 vs $\mathrm{Cg}$ (e)HPS1 vs $\mathrm{Cg}$ (f) HPS2 vs $\mathrm{Cg}$ (g) HPS3 vs $\mathrm{Cg}$, (h) KI1 vs $\mathrm{Cg}$ (i) KI2 vs $\mathrm{Cg}$, (j) KI3 vs $\mathrm{Cg}$, (k) SP1 vs $\mathrm{Cg}$, (l) SP2 vs $\mathrm{Cg}$, (m) SP3 vs $\mathrm{Cg}$, (n) SP4 vs $\mathrm{Cg}$, (o) Isolat $\mathrm{Cg}$ ( Control) 
Fungal isolates which have high inhibition power are antagonistic isolates whose colony growth is faster than pathogenic colonies and it appears that the development of antagonistic colonies can cover and suppress the development of pathogenic colonies.

In addition to the determination of growth inhibition percentage, observation of growth, colony development and pathogenic hyphae of $C$. gloesporioides was also carried out after antagonistic tests with endophytic fungi originating from 4 different farm locations and clones and the results are presented in Figure 2. Figure 2 shows that $C$. gloesporioides mycelium directly interacts with endophytic fungi that is thinner than the mycelium in the control. In endophytic fungal culture colonies, with the same incubation time, the growth of treated $C$. gloesporioides hyphae was slower, characterized by hyphae shrouded by endophytic fungi as the antagonist when compared to controls.

The dual culture test showed that the presence of fourteen endophytic fungi isolates was able to produce mycotoxins, enzymes and antibiotics which inhibited the growth of $C$. gloesporioides more than $50 \%$ as indicated by analysis of endophytic metabolites (see table 11). Therefore, these endophytes can act as antagonist agents. Amaria et al. (2015) stated that the inhibition of antagonistic fungi against pathogens in vitro is an indicator of its ability to suppress the growth of pathogens in the field, and the value of inhibitory power $>70 \%$ can be categorized as selected isolates as antagonistic agents.

The mycelium of $C$. gloesporioides in dual culture treatment of 14 endophytic isolates was thinner than the control, means as indication of competition between pathogenic and antagonistic fungi. Competition occurs when two microorganisms require a limited amount of nutrients and space. In this mechanism, antagonistic fungi will get more nutrition than pathogenic fungi, thereby inhibiting pathogenic growth. In addition, endophytic fungi grew faster on PDA media than C. gloesporioides isolates. This fast growth is beneficial for endophytic fungi, which function as antagonists in competing with phytopathogenic fungi for space and nutrients, even before their mycotoxin action (Zivkovic et al., 2010).

Desmukh et al. (2018) stated that one of the requirements for an organism to be a biological agent is the ability to antagonize or inhibit the development and growth of other organisms. Siri-Udom et al., (2015) added that the biocontrol mechanism is to weaken or kill plant pathogens with resistance, namely directly parasitizing pathogens, producing antibiotics (toxins), and their ability to compete for space and nutrition. It also produces enzymes to fight pathogenic cell components, induces plant resistance responses, and produces plant metabolism to stimulate germination of pathogenic spores.

Table 2 - Average of diameter growth of endophytic fungi colony on PDA media $(\mathrm{cm})$

\begin{tabular}{|c|c|c|c|c|}
\hline \multirow{2}{*}{ Treatment } & \multicolumn{4}{|c|}{ Colony Diameter $(\mathrm{cm})$} \\
\hline & $2 \mathrm{HSI}$ & $4 \mathrm{HSI}$ & $6 \mathrm{HSI}$ & $8 \mathrm{HSI}$ \\
\hline Control & $2.03^{\mathrm{a}}$ & $4.23^{\mathrm{C}}$ & $7.54^{\mathrm{g}}$ & $8.47^{e}$ \\
\hline HPS1 & $2.44^{\mathrm{a}}$ & $4.70^{\mathrm{C}}$ & $6.06^{d}$ & $6.53^{c}$ \\
\hline HPS2 & $2.35^{\mathrm{a}}$ & $4.59^{c}$ & $6.02^{d}$ & $6.55^{\mathrm{c}}$ \\
\hline HPS3 & $2.55^{\mathrm{a}}$ & $5.00^{d}$ & $6.78^{\mathrm{e}}$ & $7.91^{d}$ \\
\hline $\mathrm{KI} 1$ & $4.75^{\mathrm{b}}$ & $5.21^{d}$ & $7.07^{9}$ & $7.63^{d}$ \\
\hline $\mathrm{K} 12$ & $1.70^{\mathrm{a}}$ & $2.18^{a}$ & $2.95^{\mathrm{a}}$ & $3.33^{a}$ \\
\hline $\mathrm{KI} 3$ & $3.36^{\mathrm{b}}$ & $5.67^{e}$ & $7.14^{g}$ & $8.08^{e}$ \\
\hline BB1 & $1.99^{\mathrm{a}}$ & $4.65^{c}$ & $7.33^{9}$ & $8.64^{\dagger}$ \\
\hline BB2 & $2.03^{\mathrm{a}}$ & $4.74^{\mathrm{c}}$ & $7.43^{\mathrm{g}}$ & $8.30^{e}$ \\
\hline BB3 & $1.98^{\mathrm{a}}$ & $3.73^{\mathrm{b}}$ & $6.16^{\mathrm{d}}$ & $7.02^{c}$ \\
\hline BB4 & $2.65^{\mathrm{a}}$ & $5.57^{e}$ & $6.83^{\dagger}$ & $8.33^{e}$ \\
\hline SP1 & $3.34^{\mathrm{b}}$ & $5.17^{\mathrm{d}}$ & $5.88^{\mathrm{C}}$ & $6.17^{\mathrm{c}}$ \\
\hline SP2 & $2.77^{\mathrm{a}}$ & $4.26^{\mathrm{C}}$ & $5.24^{c}$ & $6.38^{c}$ \\
\hline SP3 & $2.28^{\mathrm{a}}$ & $4.16^{c}$ & $4.88^{b}$ & $5.30^{b}$ \\
\hline SP4 & $2.41^{\mathrm{a}}$ & $3.91^{\mathrm{b}}$ & $5.15^{c}$ & $6.34^{c}$ \\
\hline
\end{tabular}

Note: The numbers followed by different letter in the same column are significantly different in the $1 \%$ Duncan test.

Structural changes in the fungal hyphae of $C$. gloesporioides are an indication of these antibiotic compound's activity. According to Ainy et al. (2015), antibiotic secondary metabolite compounds will enter the fungal cells and cause mycolysis. Mycolysis is the loss of protoplasm in the cell wall structure that make enzyme does not dissolve in the cell wall of the fungus. This mycolysis causes a number of symptoms, such as swelling, shortening and 
lysis of the cell walls and results in abnormal growth of hyphae. Landecker (1996) also stated that tannins, flavonoids and phenols can inhibit the growth of mycelium and germination of fungal spores.

Phenolic compounds are alcohol groups that can bind to the hydrophobic area of the cell membrane thus disrupts and affects the integrity of the cell membrane which causes holes in the cell membrane. The presence of holes in the cell membrane results in cell lysis and denaturation of proteins inhibits the formation of cytoplasmic proteins and nucleic acids and inhibits ATP-ase bonds in the cell membrane. This mechanism inhibits the formation of cell wall components and in turn mycelium growth is inhibited.

Colony growth on PDA media showed that 14 treatments of endophytic fungi isolates were significantly different at each incubation time. The isolates growth is the colony diameter and colony area of each endophytic isolate.

Table 2 shows that the colony diameter growth of endophytic fungi isolates at 2 days after incubation varies considerably. At this stage, the isolates diameter growth of $\mathrm{KI} 1, \mathrm{KI} 3$ and SP1 was greatest. However, the control has larger colony diameter growth than some endophytic fungal isolates, such as $\mathrm{KI} 2, \mathrm{BB} 1$ and $\mathrm{BB} 3$. In the second observation (4 DAI), isolates such as KI3, BB4 and SP1 had the largest colony diameter growth.

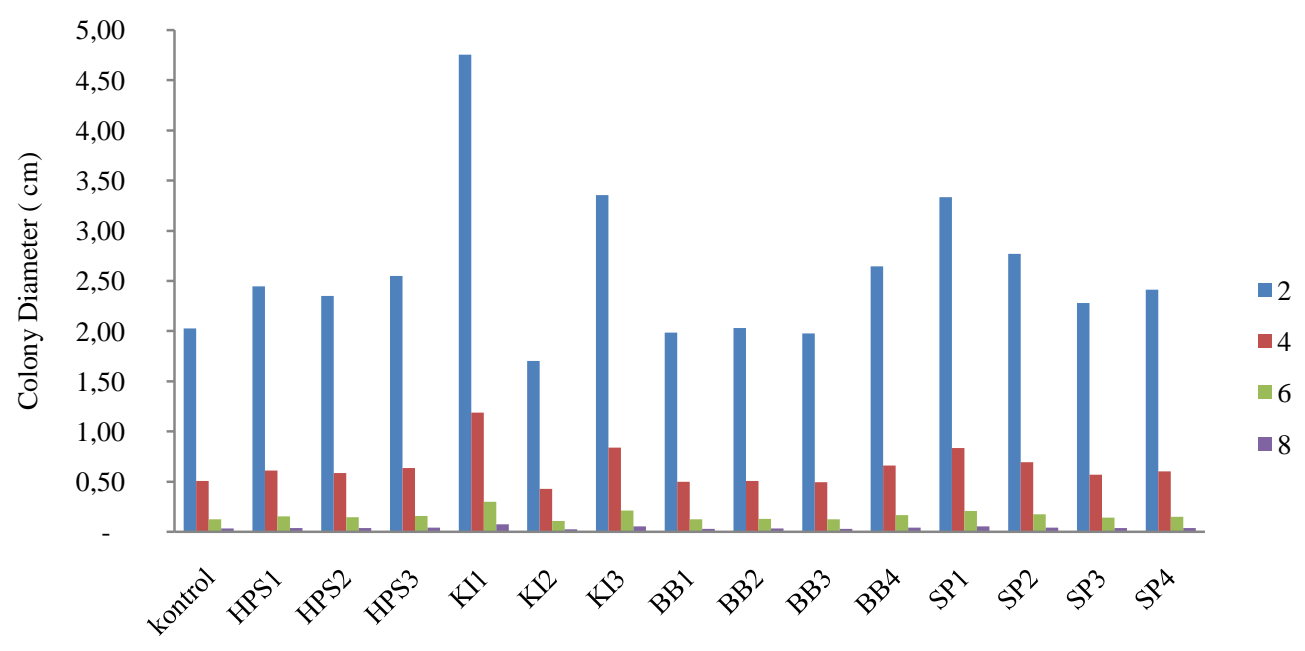

Types of Endophytic Fungus Isolates

Figure 3 - Growth of endophytic colony diameter in PDA media (cm)

Table 3 - Average of endophytic fungi colonies area on PDA media $\left(\mathrm{cm}^{2}\right)$

\begin{tabular}{lllll}
\hline \multirow{2}{*}{ Treatment } & \multicolumn{4}{c}{ Colonies Area $\left(\mathrm{cm}^{2}\right)$} \\
\cline { 2 - 5 } & $2 \mathrm{HSI}$ & $4 \mathrm{HSI}$ & $6 \mathrm{HSI}$ & $8 \mathrm{HSI}$ \\
\hline Control & $3.23^{\mathrm{c}}$ & $14.05^{\mathrm{e}}$ & $44.65^{\mathrm{g}}$ & $56.28^{\mathrm{e}}$ \\
HPS1 & $5.73^{\dagger}$ & $23.23^{\dagger}$ & $31.20^{\dagger}$ & $32.98^{\mathrm{d}}$ \\
HPS2 & $5.08^{\mathrm{e}}$ & $24.28^{\dagger}$ & $32.83^{\dagger}$ & $35.05^{\mathrm{d}}$ \\
HPS3 & $4.50^{\mathrm{e}}$ & $12.03^{\mathrm{d}}$ & $16.73^{\mathrm{c}}$ & $19.00^{\mathrm{c}}$ \\
KI1 & $5.73^{\dagger}$ & $11.18^{\mathrm{d}}$ & $21.15^{\mathrm{d}}$ & $26.53^{\mathrm{d}}$ \\
KI2 & $5.25^{\mathrm{e}}$ & $22.95^{\dagger}$ & $37.68^{\mathrm{a}}$ & $51.75 \mathrm{e}$ \\
KI3 & $4.05^{\mathrm{d}}$ & $6.83^{\mathrm{b}}$ & $12.05^{\mathrm{b}}$ & $13.95^{\mathrm{b}}$ \\
BB1 & $1.93^{\mathrm{a}}$ & $3.00^{\mathrm{a}}$ & $3.88^{\mathrm{a}}$ & $4.28^{\mathrm{a}}$ \\
BB2 & $1.85^{\mathrm{a}}$ & $2.95^{\mathrm{a}}$ & $3.28^{\mathrm{a}}$ & $4.30^{\mathrm{a}}$ \\
BB3 & $2.75^{\mathrm{b}}$ & $9.30^{\mathrm{c}}$ & $19.98^{\mathrm{d}}$ & $29.18^{\mathrm{d}}$ \\
BB4 & $3.13^{\mathrm{c}}$ & $8.68^{\mathrm{c}}$ & $12.88^{\mathrm{b}}$ & $12.75^{\mathrm{b}}$ \\
SP1 & $5.95^{\dagger}$ & $18.88^{\dagger}$ & $26.50^{\mathrm{e}}$ & $30.93^{\mathrm{d}}$ \\
SP2 & $7.05^{\dagger}$ & $21.63^{\dagger}$ & $29.25^{\dagger}$ & $35.00^{\mathrm{d}}$ \\
SP3 & $5.33^{\dagger}$ & $18.98^{\dagger}$ & $27.68^{\mathrm{e}}$ & $39.05^{\mathrm{d}}$ \\
SP4 & $5.48^{\dagger}$ & $18.30^{\dagger}$ & $25.38^{\mathrm{e}}$ & $30.53^{\mathrm{d}}$ \\
\hline
\end{tabular}

Note: The numbers followed by different letter in the same column are significantly different in the $1 \%$ Duncan test.

This growth trend is consistent up to the 6 and 8 DAI. However, the phenomenon of colony diameter growth is not linear with colony area growth. Colonies of isolates BB1 and 
BB2 had the highest colony diameter but producing the lowest colony area compared to other isolate colonies. Even the control colony area shows the largest colony area along with $\mathrm{KI} 2$, namely $56.28 \mathrm{~cm}^{2}$ and $51.75 \mathrm{~cm}^{2}$, respectively.

Table 3 shows that all tested endophytic fungi were significantly different compared to controls from $2 \mathrm{DAl}$ to $8 \mathrm{DAl}$. The growth rate of antagonistic fungi is an indicator of competition mechanisms for space and nutrients with pathogens. The faster the antagonistic fungi grow, the more effective to suppress the growth of pathogens. According to Djafaruddin (2000), the growth rate of fungal colonies is an important factor in determining its potential as a biological agent against pathogens. This is supported by Amaria and Wardiana (2014) that fungal isolates are antagonistic to plant diseases if the colony growth is faster than pathogenic colonies. Elbert et al. (2007) stated that the growth of the resulting fungal colonies has an important role in the process of its life cycle because spores/conidia are a means of asexual reproduction, spread, and fungal survival in their environment.

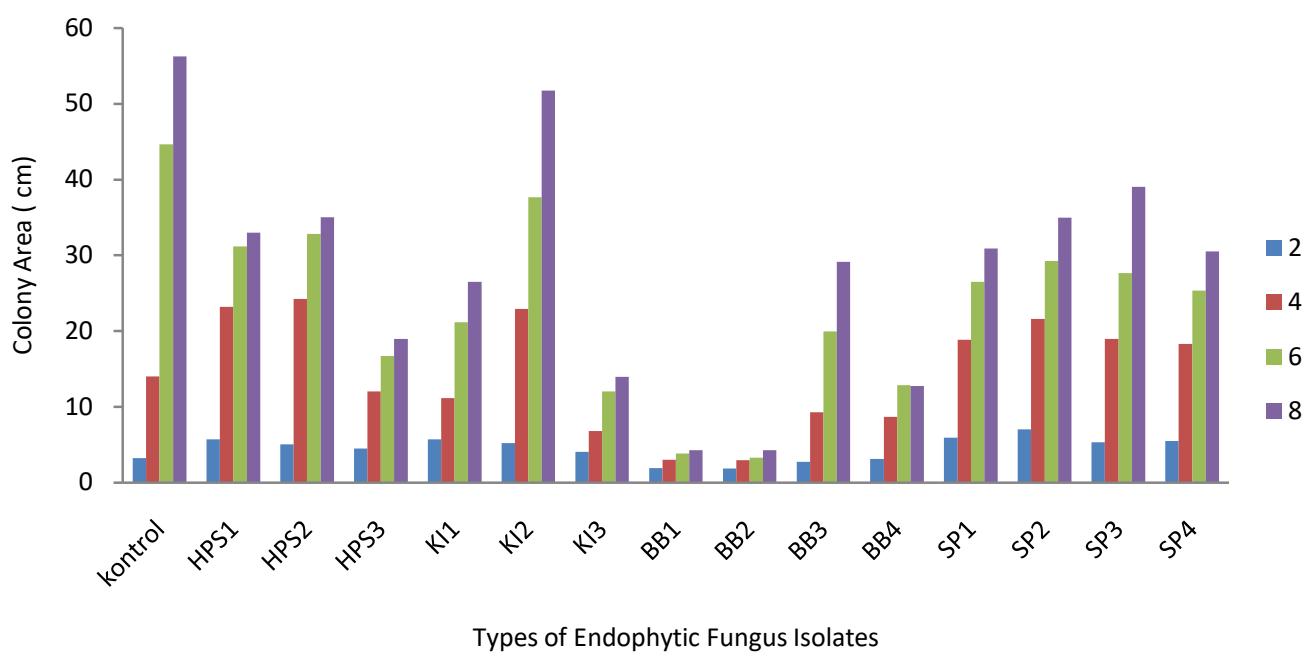

Figure 4 - Growth of Endophytic Fungal Colonies on PDA Media (cm)

The interaction mechanism between endophytic fungi and $C$. gloesporioides. Endophytic fungal isolates as shown in Figure 4 were able to suppress the growth of $C$. gloesporioides. In vitro control that accompanied by a clear zone of inhibition between endophytic fungal colonies is able to be explained by the production of antibiotics or toxic metabolites (Ding et al., 2019). These endophytic fungi produce several metabolites with specific functions as antimicrobials, and the BB1 endophytic fungi isolate can be said as good candidates for the production of antifungal compounds such as multiple culture changes in hyphal growth (eg intensive lateral branching) in all species observed. The lateral and curly branching of hyphae is known as a fungal response to antibiotics (Kumar and Kaushik, 2013) and metabolites derived from endophytes have been shown to trigger this morphogenesis (Dihonen, Sipari, Sipari and Asiegbu, 2016). Lateral branching has been found to be an avoidance strategy by the pathogen Aspergillus fumigatus to prevent contact with neutrophils (Ellett et al., 2017).

\section{CONCLUSION}

Colony growth on PDA media showed that 14 treatments of endophytic fungi isolates were significantly different at each observation time. Colonies of isolates BB1 and BB2 had the highest colony diameter but have the lowest colony area compared to other isolate colonies. The consistency of the most effective inhibition with the highest percentage of inhibitory power, namely $92.58 \%$, was found in isolates originating from Bandar Betsy 1 (BB1). 


\section{REFERENCES}

1. Ainy, E.Q., Ratnayani, R., Susilawati, L. 2015. Uji Aktivitas Antagonis Trichoderma Harzianum 11035 terhadap C. gloesporioides capsici TCKR2 dan C. gloesporioides acutatum TCK1 Penyebab Antraknosa pada Tanaman Cabai. Proceeding Biology Education Conference, 12(1): 892-897.

2. Amaria, W. \& Wardiana, E. 2014. Pengaruh waktu aplikasi dan jenis Trichoderma terhadap penyakit jamur akar putih pada bibit tanaman karet. Jurnal Tanaman Industri dan Penyegar. [Online] 1 (2), 79-86. Available from: doi:10.21082/jtidp.v1n2.2014.p7986.

3. Amaria, W., Harni, R., Samsudin. 2015. Evaluasi jamur antagonis dalam menghambat pertumbuhan Rigidoporus microporus penyebab penyakit jamur akar putih pada tanaman karet. J. TIDP 2(1), 51-60

4. Bulan, A.F.D., Nurhayati, Mazid, A. 2012. Uji Efektivitas Trichoderma sp. terhadap C. gloesporioides (Penz) penyebab penyakit gugur daunpada tanaman karet. Majalah Ilmiah Sriwijaya, 22(15): 56-68.

5. Deshmukh, S.K., Gupta, M.K., Prakash, V., Saxena, S. 2018. Endophytic Jamur: A Source ofPotentialAntifungal Compounds. J. Jamur, 4(77): 1-42. doi:10.3390/jof4030077.

6. Ding Z., Tao T, Wang L, Zhao Y, Huang H, Zhang D., Liu M., Wang Z., Han J. 2019. Bioprospecting of Novel and Bioactive Metabolites from Endophytic Fungi Isolated from Rubber Tree Ficus elastica Leaves. J. Microbiol. Biotechnol. (2019), 29(5), 731-738.

7. Djafaruddin. 2000. Dasar-dasar pengendalian penyakit tanaman. Jakarta: PT Bumi Aksara.

8. Ellett, F., Jorgensen, J., Frydman, G. H., Jones, C. N., \& Irimia, D. (2017). Neutrophil Interactions Stimulate Evasive Hyphal Branching by Aspergillus fumigatus. PLOS Pathogens, 13(1), e1006154. doi:10.1371/journal.ppat.1006154

9. Elbert, W., Taylor, P.E., Andreae, M.O., \& Pöschl, U. 2007. Contribution of jamur to primary biogenic aerosols in the atmosphere: Wet and dry discharged spores, carbohydrates and inorganic ions. Atmos. Chem. Phys., 7, 4569-4588.

10. Firdaus M, Syamsafitri, Rahayu, M.S., 2020. Uji efektivitas jamur endofit tanaman karet asal kebun Bandar Betsy sebagai agens hayati penyakit gugur daun (Colletotrichum gloeosporides) pada tanaman karet (Hevea brasiliensis Muell. Arg.). AGRILAND Jurnal Ilmu Pertanian 8(1) Januari-April 2020 41-48.

11. Jean G, Edith NO, Auguste N, Abd-Allah MO, Frank E, Henri-GreH goire NA. 2001. Effect ofkontrolling $C$. gloesporioides leaf fall of rubber tree on epidemic development andrubber production. Crop Prot, 20:581-90.

12. Hunupolagama, D.M., Chandrasekharan, N.V., Wijesundera, W.S.S., Kathriarachchi, H.S., Fernando, T.H.P.S., Wijesundera, R.L.C. 2017. Unveiling Members of Colletotrichum acutatum Species Complex Causing Colletotrichum Leaf Disease of Hevea brasiliensis in Sri Lanka. Curr Microbiol. DOI 10.1007/s00284-017-1238-6,

13. Kim YK, Wang Y, Liu ZM, Kolattukudy PE. 2002. Identification of a hard surface contactinduced gene in C. gloesporioides conidia as a sterol glycosyltransferase, a novel fungal virulence faktor. Plant J, 30:177-87.

14. Kumar S, Kaushik N. 2013. Endophytic fungi isolated from oil seed crop Jatropha curcas produces oil and exhibit antifungal activity. PLoS One 8: e56202.

15. Landecker, E. M. 1996. Fundamental of The Fungi. Fourth Edition. Prientice Hall, Upper Saddle River: New Jersey

16. Liu XJ, Yang YT, Leng HQ. 1987. Identification of species and forms of $\mathrm{C}$. gloesporioidesgloeosporioides in rubber growing regions in south China. Chin $\mathrm{J}$ Trop Crops, 8:93-101.

17. Lubbe, C.M., Denman, S., Cannon, P.F., Groenewald,J.Z., Lamprecht, S.C. and Crous, P.W. 2004.Characterization of C. gloesporioides gloeosporioidesand similar species associated withanthracnose and dieback of Proteaceae. Mycologia96: 1268-1279.

18. Münch S, Lingner U, Floss DS, Ludwig N, Sauer N, Deising HB. 2008. Thehemibiotrophic lifestyle of C. gloesporioides species. J Plant Physiol, 165:41-51. 
19. Purnomo, H. 2011. PengantarPengendalian Hayati. PT Gramedia Pustaka Utama. Jakarta.

20. Pusat Data dan Sistem Informasi Pertanian. 2019. Outlook komoditas pertanian tanaman perkebunan: Karet. Pusat Data dan Sistem Informasi Pertanian Sekretariat Jenderal Kementerian Pertanian.

21. Siri-udom, S., Suwannarach, N., Lumyong, S. 2015. Existence of Muscodor vitigenus, M. equiseti and $M$. heveae sp. nov.in leaves of the rubber tree (Hevea brasiliensis Müll. Arg.), and their biokontrol potential. Ann. Microbiol., 66, 437-448. DOI 10.1007/s13213015-1126-x.

22. Terhonen, E., Sipari, N., Asiegbu, F.O. 2016. Inhibition of phytopathogens by fungal root endophytes of Norway spruce. Biological Control, 99 (2016): 53-56. https://doi.org/10.1016/j.biocontrol.2016.04.006

23. Wang Y., and Dai, C.C. 2011. Endophytes: a potential resource for biosynthesis, biotransformation, and biodegradation. Ann. Micro- biol. 61(2): 207215.doi:10.1007/s13213-010-0120-6.

24. Zivkovic, S., Stojanovic, S., Ivanovic, Z., Gavrilovic, V., Popovic, T., \& Balaz, J. 2010. Screening of Antagonistic Ativity of Microorganism against C. gloesporioides acutatum and C. gloesporioides gloeosporoides. Arch. Boil. Sci. Belgrade, (3): 611-621. 